\title{
Authentic Leadership Questionnaire: Case of its Validation through Structural Equation Modelling; Evidence from Pakistan
}

\author{
Haroon Bakari ${ }^{1}$, Ahmed Imran Hunjra ${ }^{2}$
}

\begin{abstract}
Authentic leadership is an emerging construct which has attracted scholars and practitioners alike due to the felt need of ethical climate in organizations among rising corporate scandals. Though considerable attempts have been made to further refine the construct by undertaking validation studies in different cultures, no study has reported validation of authentic leadership questionnaire in the Pakistani context. This study offers new contributions towards the validation of the authentic leadership questionnaire from Pakistani context and reports the results of confirmatory factor analysis, reliability, and construct validity by analyzing responses from three independent nationally representative samples $(n=580)$. Such need has been felt by many authors to provide the evidence of validity in other cultures like Asia. Using structural equation modeling through AMOS, this study concludes that the authentic leadership questionnaire is a valid and reliable construct in the Pakistani culture too. The model fit indices indicate that the second order model of authentic leadership is more robust and preferable than the first order model and the composite factor. Positive impact of authentic leadership on championing and partial mediation of management support and affective commitment to change between authentic leadership and championing indicate predictive validity of authentic leadership questionnaire. Implications, limitations, and future recommendations are discussed.
\end{abstract}

Keywords: Affective commitment to change, authentic leadership questionnaire, championing, management support, Pakistan

\section{Introduction}

Authentic leadership is an emerging construct which has attracted scholars and practitioners alike (Avolio, Griffith, Wernsing, \& Walumbwa, 2010; Gardner, Cogliser, Davis, \& Dickens, 2011). In recent times when more focus is being put on the integrity

1 Lecturer, MBBS Campus Dadu, University of Sindh. Email: haroon.bakari@usindh.edu.pk

2 Assistant Professor, UIMS-PMAS-University of Arid Agriculture Rawalpindi. Email: ahmedhunjra@gmail.com

ARTICLE HISTORY
\begin{tabular}{lll}
$21 \mathrm{Dec}, 2016$ Submission Received & 1 Feb, 2017 & First Review \\
\hline 8 Feb, 2017 Revised Version Received & $25 \mathrm{Mar}, 2017$ & Second Review \\
\hline 27 Mar, 2017 Revised Version Received & $15 \mathrm{Apr}, 2017$ & Accepted
\end{tabular}


and transparency of leaders amongst ethical climate of organizations due to rise in the corporate scandals like that of Enron in USA and Axact in Pakistan (Andreoli \& Lefkowitz, 2009; Treviño, Nieuwenboer, \& Kish-Gephart, 2014).

Popularity of the authentic leadership theory among scholars is evident from the rising number of theoretical and empirical studies in the past decade and the emergence of different scales to tap the authentic leadership behaviour (Neider \& Schriesheim, 2011; Walumbwa, Avolio, Gardner, Wernsing, \& Peterson, 2008). For every emerging construct, it is necessary that it should be investigated in different cultures so that its generalizability across many cultures may be established. Though considerable attempts have been made to further refine the construct by undertaking validation studies in different cultures (Gardner, Avolio, Luthans, May, \& Walumbwa, 2005), very rare attempts have been made to test this important construct in Pakistani culture (e.g. A. Adil \& Kamal, 2016; Zubair \& Kamal, 2015) but no study has reported psychometric properties for validation of the authentic leadership questionnaire in Pakistani context.

This study offers new contributions towards the validation of the authentic leadership questionnaire from Pakistani context and reports results of confirmatory factor analysis, reliability, and validity by analyzing responses from three independent samples. Such need has been felt by many authors to provide the evidence of validity in other cultures like Asia (e.g. Banks, McCauley, Gardner, \& Guler, 2016, p. 13).

Roof (2014) who reviewed 138 papers including the samples from Canada, USA, Germany, Norway China, Taiwan, Iran and Belgium to consolidate psychometric properties of the authentic leadership questionnaire, but could not find any study from India, Pakistan and Bangladesh. Author argues that although the results regarding the validation of authentic leadership questionnaire are so far encouraging yet as the questionnaire is at its early stage and validation of new constructs is an ongoing process, therefore, there is need to undertake more studies to know whether the authentic leadership questionnaire is valid construct across different cultures (p.7). Avolio and Walumbwa (2014) also argue that major work on authentic leadership has taken place in the Western cultures therefore, answer to the question of relevance of the authentic leadership to other cultures across the world needs further exploration (p.351).

\section{Literature Review}

\subsection{Authentic Leadership}

Luthans and Avolio (2003) defined authentic leadership as a "process that draws 
from both positive psychological capacities and a highly developed organizational context, which results in both greater self-awareness and self-regulated positive behaviours on the part of leaders and associates, fostering positive self-development”. The work of Luthans and Avolio (2003) leads towards the development of the authentic leadership construct which has been so far tested in variety of contexts and has also been criticized for different reasons such as its redundancy with other leadership constructs like transformational leadership (Avolio, Walumbwa, \& Weber, 2009, p. 424; Banks et al., 2016; Gardner et al., 2011). Walumbwa et al. (2008) has provided detailed definition of authentic leadership as the behaviour of the leaders which emanates from positive organizational behaviour with major focus on ethical climate. Authors described that authentic leadership comprises four inter-related factors, these are, self-awareness, relational transparency, balanced processing and internalized moral perspective (Bakari, Hunjra, \& Niazi, 2017)

\subsubsection{Self-Awareness}

Lagan (2007) described self-awareness as the ability of a person to be aware of and accept his / her own "motives, feelings, desires, and self-relevant cognitions". In the views of Walumbwa et al. (2008) authentic leaders are aware about their own strengths and weaknesses. They not only know themselves accurately but they are aware about the context in which they are working and how this context adds meaning to their behaviour. They also know about the perception of others about them, their level of awareness of self, morality, and values (Avolio, Gardner, Walumbwa, Luthans, \& May, 2004 , p. 4). Authentic leadership is 'being yourself' and understanding the passions and motivations (George, 2003, p. 11).

\subsubsection{Relational transparency}

Relational transparency refers how transparently and truly the leaders communicate with others; it is the exposure of one's own real and genuine self in contrast to inaccurate, biased and fake self (Gardner et al., 2011). By demonstrating their true self, leaders can easily gain the trust of their followers and enhance their commitment to the organization and leadership (Gardner et al., 2005; Kernis, 2003). Relationally transparent leaders do not hide anything rather they say exactly what they mean to say, realize their mistakes if committed, invite others' comments and criticism on their own decisions, actions and personality, propagate truth and possess harmony in their emotions and feelings (Bakari et al., 2017; Gardner et al., 2011).

\subsubsection{Balanced processing}

Balanced processing, as the name suggests, is concerned with the leaders' behaviour characterized by their ability to process the true and relevant information 
objectively before inferring any conclusion during decision-making (Walumbwa et al., 2008, p. 95). This is related to transparent decision making based on objective analysis of data, incorporating views from all relevant quarters, inviting and welcoming opposite thoughts that may challenge their long rooted beliefs, being impartial while processing information and avoiding exaggeration and distortion of facts (Gardner et al., 2005; Kernis, 2003). Balanced processing results in the integrity of decision-making, followers' sense of supportiveness of their leaders, and followers' psychological capital (Gardner et al., 2005; Ilies, Morgeson, \& Nahrgang, 2005).

\subsubsection{Internalized moral perspective}

To be aware of one's own personal and core values, and ability to foster these values in followers is called internalized moral perspective (Luthans \& Avolio, 2003). It is a kind of self-regulation in which behavior is adjusted to carry out equitable and fair decision making based on the high standard of ethical conduct. These decisions reflect not only values that are propagated by leader's practices and proposed by leaders but core values of organizations, groups, and society as a whole (Avolio \& Gardner, 2005). Authentic leaders through internalized moral perspective identify and analyze core ethical issues and feel responsibility to deal with issues following well-established ethical manner. It is the lens through which authentic leaders recognize ethical dilemmas, evaluate options, and take necessary action authentically (May, Chan, Hodges, \& Avolio, 2003).

Empirical literature reveals that authentic leadership is related to different outcomes such as job satisfaction (Laschinger et al., 2016; Onorato \& Zhu, 2015; Penger \& Černe, 2014), structural empowerment (Read \& Laschinger, 2015; Wong \& Laschinger, 2013), psychological empowerment (Shapira-Lishchinsky \& Tsemach, 2014), personal identification and trust (Fox, Gong, \& Attoh, 2015; Wong, Spence Laschinger, \& Cummings, 2010), organizational identification (García-Guiu, Molero, \& Moriano, 2015), psychological capital (Amunkete \& Rothmann, 2015; Woolley, Caza, \& Levy, 2010), intention to leave (Laschinger \& Fida, 2014), workplace bullying (Warszewska-Makuch, Bedyńska, \& Żołnierczyk-Zreda, 2015), organizational justice (García-Guiu et al., 2015), work engagement (Giallonardo, Wong, \& Iwasiw, 2010), work climate (Nelson et al., 2014), psychological well-being (Nelson et al., 2014), creativity and innovativeness (Müceldili, Turan, \& Erdil, 2013), management support for innovation (Cerne, Jaklic, \& Skerlavaj, 2013), cynicism (Laschinger et al., 2016; Laschinger \& Fida, 2014), voice behaviour (Hsiung, 2012; Wong et al., 2010), commitment (Darvish \& Rezaei, 2011; Gatling, Kang, \& Kim, 2016; Rego, Lopes, \& Nascimento, 2016), behavioural integrity (Leroy, Palanski, \& Simons, 2012), Performance (Leroy, Anseel, Gardner, \& Sels, 2015; Leroy et al., 2012), extra effort (Jacques, Garger, Lee, \& Ko, 2015; Peus, Wesche, Streicher, Braun, \& Frey, 2012), inter-professional collaboration (Regan, Laschinger, \& Wong, 2016), Self-Effi- 
cacy (Rego et al., 2016), citizenship behaviour (Cottrill, Denise Lopez, \& Hoffman, 2014; Shapira-Lishchinsky \& Tsemach, 2014) to name the few. Despite popularity of authentic leadership in positive organizational theory, no study has been found that have investigated role of authentic leadership in the context of organizational change, such need has been felt by authors like Williams, Pillai, Deptula, and Lowe (2012), this study also fills this gap too.

\subsection{Authentic Leadership, Management Support for and Affective Commitment to Change, and Championing}

To provide the evidence of predictive validity of AL, some hypotheses are formulated and tested using the data of employees of Pakistan Railways. We begin with the description of empirical literature on the relationship among authentic leadership, management support for change, affective commitment to change, and behavioural support for change.

\subsubsection{Role of authentic leadership in employees' support for change}

Leaders are thought to be primarily responsible for the success and failure of any planned change initiative (Battilana, Gilmartin, Sengul, Pache, \& Alexander, 2010; Hina Jawaid, Berntson, Baraldi, Näswall, \& Sverke, 2010). Leaders set the stage for the successful internalization of the change program at the hands of employees by providing them meaningful support, sharing information, participating in decision making, and above all setting a personal example as being true, transparent, and credible leader (Bouckenooghe, 2012; Burnes \& By, 2011; Carmeli, Schaubroeck, \& Tishler, 2011; Lines, Sullivan, \& Wiezel, 2016).

Herscovitch and Meyer (2002) defined championing as an employees' behaviour of supporting the change beyond what is expected from them. Employees not only themselves put extra effort for the success of change program but they involve others to embrace the change. Although no study has been found that may have instigated authentic leadership in the context of the change, this study endeavors to provide relevance of authentic leadership in change management. Empirical literature suggests that authentic leadership has been found positively related to employees' extra effort surrogate to championing (Jacques et al., 2015; Peus et al., 2012). Williams et al. (2012) also felt the need to test authentic leadership in employees' support for change thus, we infer following hypothesis:

H1: Authentic leadership is positively related to championing behaviour.

\subsubsection{Mediating role of management support and affective commitment to change}

Theory of authentic leadership converging both leadership ethics and the theory 
of positive organizational behaviour (Walumbwa et al., 2008) suggests that authentic leaders can influence employees' behaviours by fostering positive beliefs in employees such as a study found authentic leadership positively impacted employees' organizational commitment through mediation of psychological capital (Rego et al., 2016).

The authentic leadership has also been tested in the context of innovation and creativity by Cerne et al. (2013). Analyzing multilevel dyadic model, authors found authentic leadership positively related to creativity and innovation at individual and team levels, whereas, employees' perception of management support mediated the relationship between authentic leadership and creativity. Another study by Joo, McLean, and Yang (2013) argued that authentic leaders through their transparency and support mechanism create an environment conducive to embrace the change and enhance creativity in the face of uncertainty and ambiguity. They argued that employees will likely support the change, if they think that their leaders are 'fair and supportive' (p.406). Authors like Santhidran, Chandran, and Borromeo (2013) have also suggested to check the likely mediating role of employee perceptions of change - supportive management between leadership and employee behavioural support for change in some other Asian countries. Thus, we hypothesize following:

H2: Management support for change mediates the relationship between authentic leadership and championing

Research suggests that commitment to change (Herscovitch \& Meyer, 2002) especially affective commitment to change has been regarded as important predictor of behavioural support for change (Bouckenooghe, Schwarz, \& Minbashian, 2015) but how it facilitates leadership intervention in bringing support for the change is less knowm (M. Choi, 2011). Hill, Seo, Kang, and Taylor (2012) who found positive impact of trnasformational leadership on commitment to change suggested that commitment to change may mediate the relationship between leadership and chamioning behaviour of behavioural support for change (p.773).

van der Voet (2015) found positive impact of direct supervisors' transformational leadership style on affective commitment to change in public sector context of Netherland. Kiersch and Byrne (2015) found positive and significant relationship of authentic leadership to affective commitment. The relationship was mediated by employee perception of justice. Based on the suggestions of the authors, it is important to note that affective commitment to change may facilitate authentic leadership in the organizational change. Thus, we infer the following hypothesis:

H3: Affective commitment to change mediates the relationship between authentic leadership and championing behaviour 


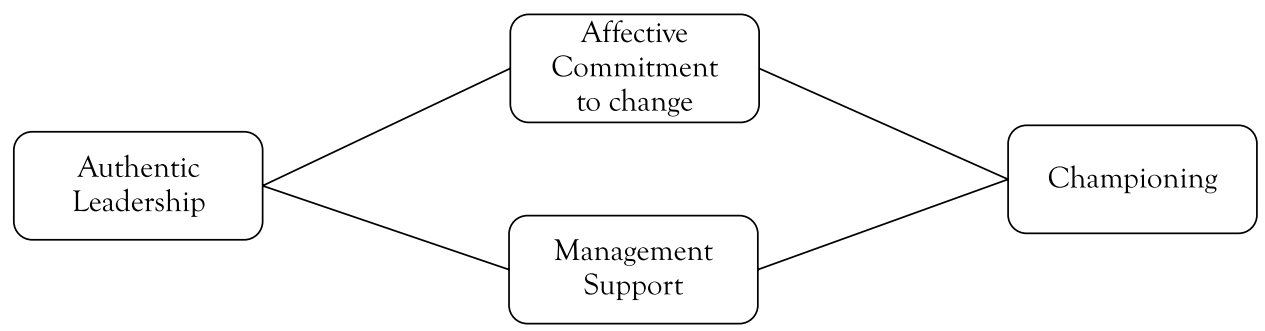

Figure 1. Conceptual Framework

\section{Methodology}

\subsection{Design}

This study has used exploratory research design and collected data from three independent samples through online and paper and pencil survey. Collected data is analyzed using SPSS and AMOS software for confirmatory factor analysis and hypothesis testing.

\subsection{Research Setting, Sample, and procedure}

Sample 1. Initially an online link of 16-item ALQ was sent to 400 faculty members of the universities of Pakistan through their official emails sought through respective Quality Enhancement Cells. At least three reminders were sent to them every two months. We received 104 responses yielding response rate of 25\%. The majority of respondents were from two major agricultural universities of the Punjab province, a military university at Islamabad, a large general university at Jamshoro, Sindh and some other universities. The sample included 29 (28\%) females; having mean age of 35 years and most of them were Ph.D degree holders i.e. 39 (37\%).

Sample 2. The second sample comprised of the employees of three health sector organizations of Sindh province undergoing structural changes. About 260 respondents returned usable questionnaire out of 340 distributed yielding the response rate of $74 \%$. Majority of the respondents were male 190 (73\%), number of doctors, nurses and para medical staff was 51, 62 and 131 respectively. From employees' age perspective 74 employees were in the age bracket of 31 to 40 years. This sample was also highly educated having 144 (55\%) graduate degree holders.

Sample 3. The third sample included the responses form 216 employees of Pakistan Railways working at different levels of employment. The responses were collected from a main $\mathrm{HQ}$, four divisional headquarters and various railways stations across Pakistan. The majority of respondents were male (90\%) and having mean age of 38 years. $60 \%$ respondents reported their education as intermediate level. Pakistan 
Railways was selected as it has been under massive reforms in recent times. Various efforts have been made to improve services of Pakistan Railways. These reforms resulted slight increase in number of passengers carried (47,690 in FY 2013-14 to 52,951 in FY 2014-15), passenger kilometers (19,778,557 in FY 2013-14 to 20,288,038 in FY 2014-15) and gross earnings in rupees (22,800,217 in FY 2013-14 to 31,924,757 in FY 2014-15) (Pakistan-Railways, 2015).

It must be noted that the sample 2 was a part of a major study aimed to tap the employees' perceptions during organizational change and role of authentic leadership in fostering employee support for planned change (Bakari, 2016; Bakari et al., 2017). Part of third sample has been reported in validation study of readiness for change scale (under preparation). This study reports the results regarding the validity of the Authentic Leadership Questionnaire (ALQ) and its relationship with employee perceptions and behaviours in order to provide the evidence of reliability and validity of ALQ in Pakistani setting.

\subsection{Measurement and Data Collection}

To tap authentic leadership, a 16-item scale developed by Walumbwa et al. (2008) has been used with the permission from copyright owners (i.e. mindgarden.com). Five point Likert scale ranging from 1 for strongly disagree to 5 for strongly agree was used to record the responses of employees. To measure management support, 6-item scale of Holt, Armenakis, Feild, and Harris (2007) has been used, whereas, affective commitment to change (6 items) and championing behaviour (6 items) has been taken from Herscovitch and Meyer (2002) scales of commitment to change and behavioural support for change respectively.

\section{Results}

\subsection{Measurement Model Estimation}

To confirm the factor structure of ALQ, this study used confirmatory factor analysis (CFA) which is the procedure used to test the extent to which the measurement model is valid. It also explores the data set and helps researcher to find out set of factors which may possibly symbolize data (Hair, Black, Babin, \& Anderson, 2010). Main objective of CFA is to measure the validity of measurement factors available in variables within the theoretical framework (Steenkamp \& Baumgartner, 2000). The criteria used to investigate model fitness and other psychometric properties are summarized in table 1 .

4.1.1 Item reliability 
Table 1: Standardized Values of Adopted Goodness of fit Statistics

\begin{tabular}{|c|c|c|c|c|}
\hline \multirow{2}{*}{ Fit indices } & Range & \multicolumn{3}{|c|}{ Acceptance criteria } \\
\cline { 3 - 5 } & $\begin{array}{c}\text { Best/excellent } \\
\text { fit: }\end{array}$ & $\begin{array}{c}\text { Reasonably } \\
\text { acceptable: }\end{array}$ & Poor fit \\
\hline $\begin{array}{c}\text { Relative / Normal chi- } \\
\text { square (CMIN/ DF) }\end{array}$ & $\begin{array}{c}(1.00<\mathrm{CMIN} / \\
\text { DF <5.00) }\end{array}$ & $1-3$ & $3-5$ & above 5 \\
\hline $\begin{array}{c}\text { Goodness Fit Index (GFI) } \\
(0.90<\mathrm{GFI} \\
<1.00)\end{array}$ & $\geq 0.95$ & $\geq 0.90$ & $<0.90$ \\
\hline $\begin{array}{c}\text { Adjusted Goodness Fit } \\
\text { Index (AGFI) }\end{array}$ & $\begin{array}{c}(0.80<\mathrm{AGFI} \\
<1.00)\end{array}$ & $\geq 0.90$ & $\geq 0.80$ & $<0.80$ \\
\hline $\begin{array}{c}\text { Comparative Fit Index } \\
\text { (CFI) }\end{array}$ & $\begin{array}{c}(0.90<\mathrm{CFI} \\
<1.00)\end{array}$ & $\geq 0.95$ & $\geq 0.90$ & $<0.90$ \\
\hline $\begin{array}{c}\text { Root Mean Square } \\
\text { Error of Approximation } \\
\text { (RMSEA) }\end{array}$ & $\begin{array}{c}(0.01<\mathrm{RMSEA} \\
<1.00)\end{array}$ & $<0.05$ & $0.06-0.08$ & above 0.10 \\
\hline
\end{tabular}

In order to measure relative contribution of each item to a particular factor, the criteria of factor loadings are applied (Harmann, 1976). All factor loadings should be statistically significant $(\mathrm{p}<0.05)$ and value of factor loadings greater than .5 is preferable. Table 2 shows the standardized regression weights (factor loadings) achieved through AMOS Graphics 18.0 for the authentic leadership and its 4 dimensions.

\subsubsection{Convergent validity}

Convergent validity is a measure to assess the shared variance among variables. To measure convergent validity each item is considered as a different approach to measure the construct and to know whether all items converge on same construct (Kiratli, Rozemeijer, Hilken, de Ruyter, \& de Jong, 2016, p. 6), to determine this, first, we examined factor loadings as shown in table 2. Strength and direction of factor loadings indicate that all values of factor loading are positive and greater than .50 and statistically significant $(p<.05)$ thus indicate existence of convergent validity. The factor loadings of item labelled as SA2 is .40 in higher education sample which is also acceptable as per the criteria of Cua, McKone, and Schroeder (2001). Second, we calculated average variance extracted (AVE) and table 3 enlists the values of AVE that are above 0.50 in all cases except for SA, IM and RT in higher education sample, so it represents existence of convergent validity (Fornell \& Larcker, 1981).

\subsubsection{Construct reliability}

To establish reliability of the scale, composite reliability (CR) computed through formula (Fornell \& Larcker, 1981) using factor loadings obtained through CFA and 


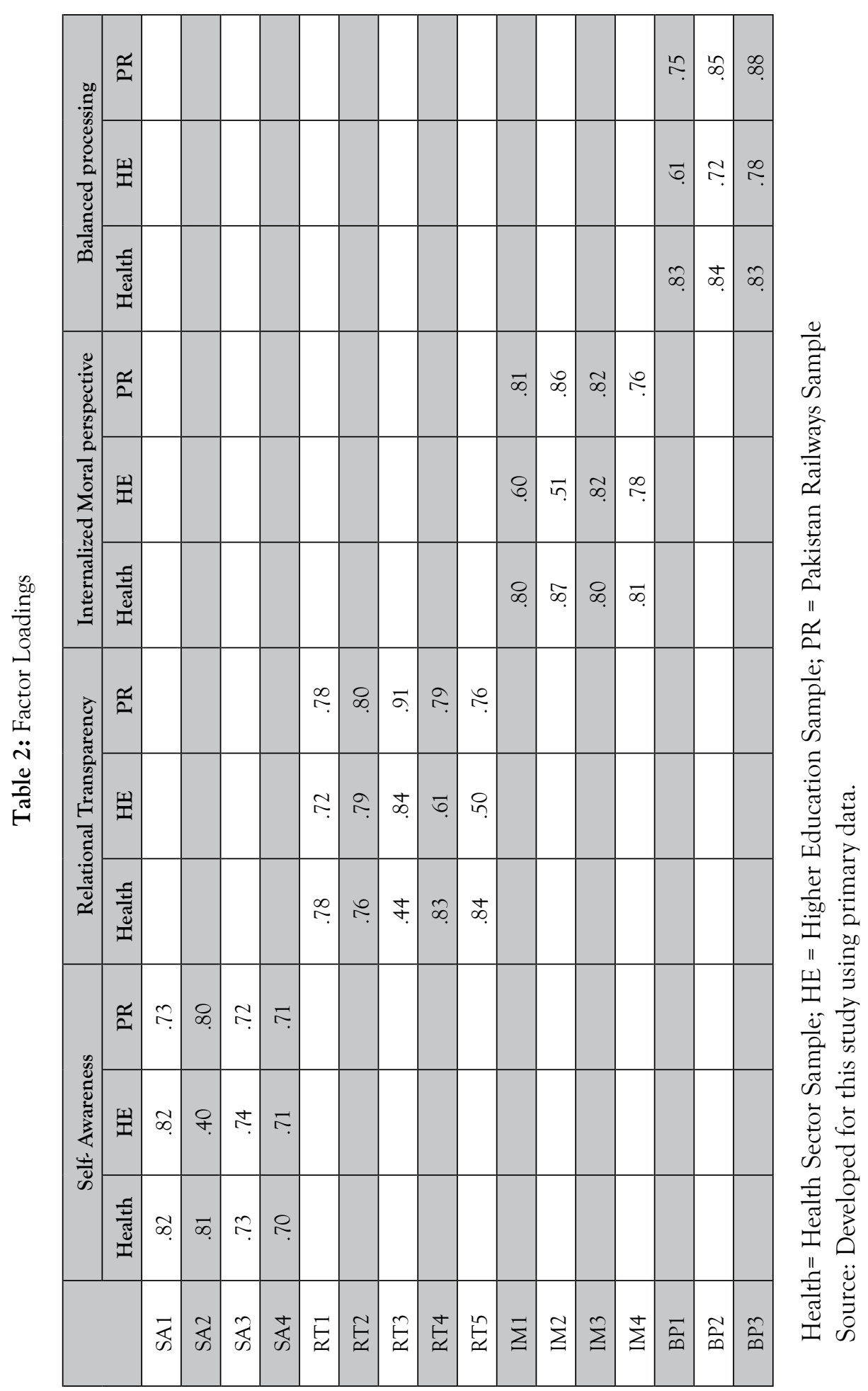


Cronbach's alpha (Cronbach, 1951) are used. Researchers suggest that the value greater than 0.60 indicate a better reliability (Bagozzi, Yi, \& Phillips, 1991; Hair et al., 2010). The values of CR and Cronbach's Alpha as enlisted in table 3 are higher than the cut-off criteria of .70 (DeVellis, 1991) thus indicate the reliability of ALQ. The AVE values for four factors in HE sample are .47, .48, .48 and .50 for SA, RT, IM and BP respectively which are slightly lower than cut-off criteria of .50 except that of BP. AVE for sample 2 and 3 are all higher than .50 (range .50 to .70). Cronbach's alpha score of self-awareness ranges from .78 to 85 , for relational transparency .80 to .82 , for internalized moral perspective .77 to .89 and for balanced processing .74 to .90 in all three samples. Alpha values for full 16 items ALQ are .93, .93 and .96 for health, education, and Railways samples respectively.

\subsubsection{Discriminant validity}

This study also attempted to report the discriminant validity of authentic leadership factors that is whether authentic leadership factors share more variance with its own factors than with other related constructs (Kiratli et al., 2016). Discriminant validity is also used to establish the distinctiveness of a construct from another. It means to determine whether the construct which is supposed to be different from other constructs in the study is actually different.

To measure the discriminant validity this study followed Fornell and Larcker (1981) who suggest that 'the square root of the focal construct's average variance extracted should exceed its correlation with related constructs' (Kiratli et al., 2016).

Table 3: Construct Reliability and AVE

\begin{tabular}{|c|c|c|c|c|c|c|c|c|c|c|c|c|c|c|c|}
\hline & \multicolumn{3}{|c|}{$\begin{array}{l}\text { Self- Awareness } \\
\text { (4 items) }\end{array}$} & \multicolumn{3}{|c|}{$\begin{array}{c}\text { Relational } \\
\text { Transparency (5 } \\
\text { items) }\end{array}$} & \multicolumn{3}{|c|}{$\begin{array}{l}\text { Internalized } \\
\text { Moral perspec- } \\
\text { tive ( } 4 \text { items) }\end{array}$} & \multicolumn{3}{|c|}{$\begin{array}{c}\text { Balanced } \\
\text { processing }(3 \\
\text { items) }\end{array}$} & \multicolumn{3}{|c|}{ Total (16 items) } \\
\hline & HS & HF & DD & HS & HE & PR & HS & $\mathrm{HE}$ & PR & HS & HE & PR & HS & $\mathrm{HE}$ & PR \\
\hline CR & .85 & .77 & .82 & .85 & .82 & .90 & .89 & .78 & .88 & .87 & .75 & .90 & & & \\
\hline AVE & .59 & .47 & .53 & .55 & .48 & .66 & .67 & .48 & .66 & .69 & .50 & .70 & & & \\
\hline$\alpha$ & .85 & .78 & .82 & .80 & .82 & .90 & .89 & .77 & .88 & .87 & .74 & .90 & .93 & .93 & .96 \\
\hline
\end{tabular}

$\mathrm{CR}=$ composite reliability; $\mathrm{AVE}=$ average variance extracted; $\alpha=$ Cronbach's alpha; HS = health sector sample; HE = higher education sample; PR = Pakistan Railways sample.

Source: Developed for this study using primary data. 
Table 4 indicates that the square root of AVE for self-awareness (SA) is 73 ( $\sqrt{\mathrm{AVE}}$ of $\mathrm{SA}=0.73$ ), whereas, correlation of $\mathrm{SA}$ with other constructs like relational transparency, balanced processing, moral perspective, championing, affective commitment to change, and management support for change are .576, .737, .688, .265, .382, .335 respectively. Results show that authentic leadership dimensions are not much distinct from each other thus supporting the existence of second order factor model (Walumbwa et al., 2008), whereas, on the other hand discriminant validity of au-

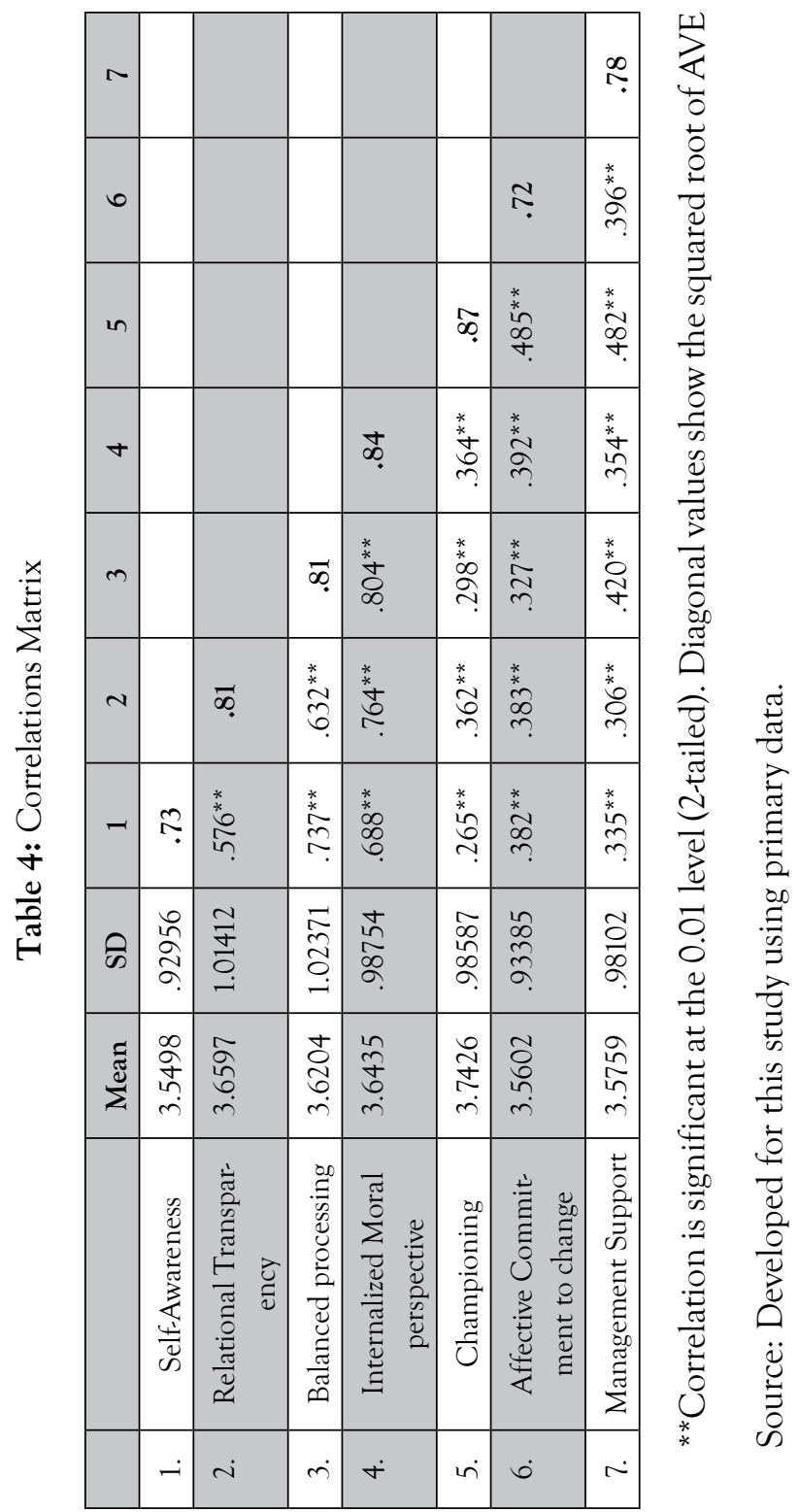


thentic leadership factor with regard to related constructs of management support, affective commitment to change, and championing behaviour is evidenced by higher squared AVE values than corresponding construct correlations of respective constructs (Fornell \& Larcker, 1981).

\subsubsection{Confirmation of factor structure of $A L Q$}

Walumbwa et al. (2008) during the development and validation process of authentic leadership questionnaire conducted CFA using AMOS to check whether the second order factor existed for the authentic leadership. Using data of 224 employees from USA, they tested three alternatives; first alternative was one factor model in which all 16 items of authentic leadership were grouped to form one grand authentic leadership factor, in second alternative all items loaded on their respective factor i.e self awareness, balanced processing, moral / ethical, and relational transparency and factors were connected to correlate with each other, third option was second-order model. In this model all items were subject to load on their respective factor / dimesnion and all factor were to laod on second order authenitc leadership factor. Using CFI, RMSEA, and chi square fit indice, they compared three models and found second order model best fitting, robust and preferable to other models. While some studies have also reported a composite score of 16 items as single factor model (Gardner et al., 2011). A recent study by Penger and Černe (2014) have also commented that conceptual similarity exists among four dimensions of authentic leadership, therefore, one single factor of authentic leadership may be used as it will explain better overlap among dimensions (p.515).

Following the same procedure, this study has also attempted to check which of the three factor structures fits well to the data. Analysis of table 5 reveals that in sample 1, all the three options yielded the results which meet the cut-off criteria. The values of relative chi square are less than 3 for sample 1 in all three models which shows excellent fit of model to the data. The values of CFI are all greater than .90 and RMSEA is less than or equal to .08 thus sample 1 which included highly qualified respondents of higher education sector of Pakistan revealed that ALQ is highly valid construct. Whereas, in sample 2, where the responses from doctors, nurses, and para medical staff of Sindh province of Pakistan were analyzed, results revealed that second order factor model yields better results as compared to other two options, and the same is true for third sample comprised of employees of Pakistan Railways. These results are in line with previous literature (e.g. Walumbwa et al., 2008).

\subsection{Structural Model Estimation}

To test the predictive power of authentic leadership, a structural model is created. 
Table 5: Comparison of a priori Authentic Leadership Questionnaire Factor Structure

\begin{tabular}{|c|c|c|c|c|c|c|c|}
\hline \multirow{2}{*}{$\begin{array}{l}\text { Factor Structure } \\
\text { Cut-off criteria }\end{array}$} & $\chi^{2}$ & $\mathrm{df}$ & $\mathrm{p}$ & $\chi 2 / \mathrm{df}$ & $\Delta \chi^{2}$ & CFI & RMSEA \\
\hline & & & & $(3-5)$ & & $(\geq 0.90)$ & $\begin{array}{c}(.06- \\
.08) \\
\end{array}$ \\
\hline \multicolumn{8}{|l|}{$\begin{array}{l}\text { Higher Education } \\
\text { Sample }(\mathrm{n}=104)\end{array}$} \\
\hline $\begin{array}{c}\text { One-factor model } \\
\text { (all } 16 \text { items) }\end{array}$ & 182.451 & 104 & .000 & 1.754 & & .91 & .08 \\
\hline $\begin{array}{c}\text { First-order factor } \\
\text { model }\end{array}$ & 164.039 & 98 & .000 & 1.674 & 18.412 & .94 & .07 \\
\hline $\begin{array}{l}\text { Second-order } \\
\text { factor model }\end{array}$ & 173.227 & 100 & .000 & 1.732 & 9.224 & .94 & .08 \\
\hline \multicolumn{8}{|l|}{$\begin{array}{c}\text { Health Sector } \\
\text { sample }(\mathrm{n}=250)\end{array}$} \\
\hline $\begin{array}{l}\text { One-factor model } \\
\text { (all } 16 \text { items) }\end{array}$ & 653.790 & 104 & .000 & 6.286 & & .91 & .14 \\
\hline $\begin{array}{c}\text { First-order factor } \\
\text { model }\end{array}$ & 335.946 & 98 & .000 & 3.428 & 317.844 & .92 & .09 \\
\hline $\begin{array}{l}\text { Second-order } \\
\text { factor model }\end{array}$ & 308.493 & 98 & .000 & 3.148 & 345.297 & .93 & .09 \\
\hline \multicolumn{8}{|l|}{$\begin{array}{l}\text { Pakistan Railways } \\
\quad(\mathrm{n}=263)\end{array}$} \\
\hline $\begin{array}{c}\text { One-factor model } \\
\text { (all } 16 \text { items) }\end{array}$ & 406.080 & 104 & .000 & 3.905 & & .88 & .11 \\
\hline $\begin{array}{c}\text { First-order factor } \\
\text { model }\end{array}$ & 299.277 & 98 & .000 & 3.054 & 106.803 & .92 & .09 \\
\hline $\begin{array}{l}\text { Second-order } \\
\text { factor model }\end{array}$ & 303.545 & 100 & .000 & 3.035 & 102.535 & .92 & .09 \\
\hline
\end{tabular}

Source: Developed for this study using primary data.

We report hypothesis testing through structural equation modeling using AMOS 18.0 software. For the mediation analysis, there are variety of procedures applied to test the effect of intervening variable on the relationship between predictor and outcome variable, three methods are widely used. First, causal steps approach suggested by Baron and Kenny (1986) is frequently and most widely used (Hayes, 2009). In this approach authors suggest that three steps must be met before proceeding to mediation; the relationship between independent and dependent variable (1st step), independent and mediator ( 2 nd step), mediator and dependent variable (3rd step) must be significant, only then mediation analysis can be done 
Second popular method is Product of Coefficients Strategy which is the extension of the causal approach. In this approach path from independent variable to mediator (a) and from mediator to dependent variable (b) are same as in causal approach. For the determination of path 'c' i.e. from independent variable to dependent variable, first, the product of beta coefficients of paths ' $a$ ' and 'b' is obtained which is then divided by the product of standard errors of ' $a$ ' and 'b'. For this, several formulas are used. Most popular is Sobel's test (Sobel, 1982). This approach relies on the assumption of normality which is not possible in the case of small sample (Bollen \& Stine, 1992), to overcome this, Preacher and Hayes (2004) suggested a bootstrapping technique.

Third, bootstrapping technique resamples the original sample and draws a new sample which then computes direct, indirect, and total effects. This is the highly sophisticated method and equally powerful in simple and multiple mediating models. Like the Sobel's test, bootstrapping is sometimes considered as supplement to causal steps method (Hayes, 2009).

Despite sophistication of Bootstrap method this study has applied SEM and reported hypothesis testing in simple mediation models using individual mediators with individual dependent variable, following Baron and Kenny (1986) approach as it is widely used in the social sciences, easy to understand, simple to explain the causal paths and their effects (Hayes, 2009, p. 411). This method is still used widely in very recent articles being published in impact factor journals (e.g. Yoon, Jang, \& Lee, 2016).

\subsection{Mediation analysis}

\subsubsection{Direct effects: Authentic leadership and championing}

The figure 2 depicts the relationship between independent variable (authentic leadership) and the dependent variable (championing behaviour of behavioural support for change). The standardized regression coefficient between authentic leadership

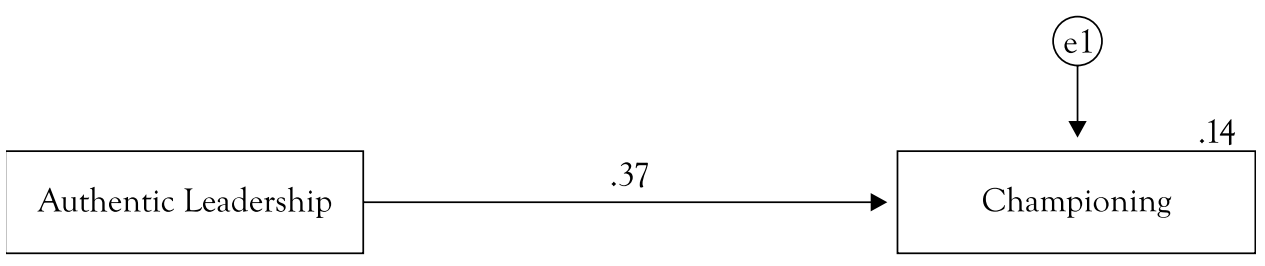

Figure 2: Authentic Leadership and Championing

and championing is 0.369 (see Table 6) and it is statistically significant $(\mathrm{p}<0.05)$. Therefore, the $\mathrm{H} 1$ is accepted.

4.3.2 Indirect effects: Mediating role of MS between AL and Championing 
The relationship between authentic leadership and management support is significant at 0.001 level (two-tailed) and its regression coefficient is 0.398 . Thus, 2 nd

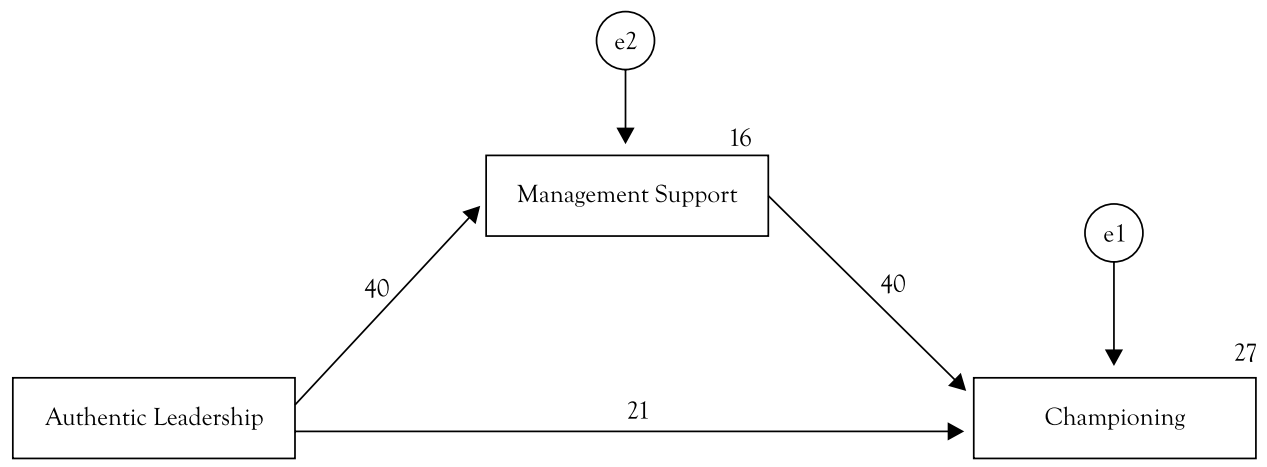

Figure 3: Mediation of MS

Table 6: Regression Coefficients

\begin{tabular}{|c|c|c|c|c|c|}
\hline & Hypothesis & Path & Direct paths $\beta$ & $\begin{array}{c}\text { Indirect paths } \\
\beta \\
\end{array}$ & Support \\
\hline \multicolumn{6}{|c|}{ Role of AL on Championing } \\
\hline 1 & $\begin{array}{c}\text { AL positively and } \\
\text { significantly influence } \\
\text { championing }\end{array}$ & $\mathrm{AL} \rightarrow$ Champ & $.369^{* * *}$ & & H1 supported \\
\hline \multicolumn{6}{|c|}{ Mediating role of MS between AL and Championing } \\
\hline 2 & $\begin{array}{c}\text { AL positively and } \\
\text { significantly influence } \\
\text { management support }\end{array}$ & $\mathrm{AL} \rightarrow \mathrm{MS}$ & $0.398^{* * *}$ & & $\begin{array}{l}\text { 2nd step } \\
\text { supported }\end{array}$ \\
\hline 3 & $\begin{array}{c}\text { Management support } \\
\text { and championing }\end{array}$ & $\begin{array}{l}\mathrm{MS} \rightarrow- \\
\text { CHAMP }\end{array}$ & $0.398^{* * *}$ & & $\begin{array}{l}3 \text { rd step sup- } \\
\text { ported }\end{array}$ \\
\hline 4 & $\begin{array}{l}\text { MS mediates between } \\
\text { AL and Championing }\end{array}$ & $\begin{array}{c}\mathrm{AL} \rightarrow \mathrm{MS} \rightarrow \\
\mathrm{CHAMP}\end{array}$ & $.369^{* * *}$ & $0.211^{* * *}$ & H2 supported \\
\hline \multicolumn{6}{|c|}{ Mediating role of ACC between AL and Championing } \\
\hline 5 & $\begin{array}{l}\text { AL positively and signifi- } \\
\text { cantly influence ACC }\end{array}$ & ALvACC & $0.425^{* * *}$ & & $\begin{array}{c}\text { 2nd step } \\
\text { supported }\end{array}$ \\
\hline 6 & ACC and championing & $\begin{array}{l}\mathrm{ACC} \rightarrow- \\
\text { CHAMP }\end{array}$ & $0.400^{* * *}$ & & $\begin{array}{l}\text { 3rd step sup- } \\
\text { ported }\end{array}$ \\
\hline 7 & $\begin{array}{l}\text { ACC mediates between } \\
\text { AL and championing }\end{array}$ & $\begin{array}{c}\mathrm{AL} \rightarrow \mathrm{ACC} \rightarrow- \\
\mathrm{CHAMP}\end{array}$ & $.369 * * *$ & $0.199^{* *}$ & H3 supported \\
\hline
\end{tabular}

${ }^{* * *} \mathrm{p}<0.001 ;{ }^{* *} \mathrm{p}<0.01$

Source: Developed for this study using primary data. 
step is supported. The mediator, management support is showing positive regression coefficients with championing $(0.398 ; \mathrm{p}<0.05)$. This indicates that both relationships are significant. Therefore, $3 \mathrm{rd}$ step is also supported. As three steps suggested by Baron and Kenny (1986) are satisfied, the study proceeds to identify the mediation effects.

According to Baron and Kenny (1986), mediation exists when the effect of independent variable on dependent variable is reduced after the introduction of the mediator in the relation. The table 6 depicts that the standardized regression coefficient of the relationship between authentic leadership and championing before the introduction of mediator is 0.369 and after the introduction it is reduced to 0.211. The relation is significant. This means that relationship between authentic leadership and championing is partially mediated by management support. The results therefore provide support for hypothesis 2 that management support for change mediates the relationship between authentic leadership and championing behaviour of behavioural support for change.

\subsubsection{Indirect effects: Mediating role of ACC between AL and Championing}

The figure 4 shows mediation of affective commitment to change. Results indi-

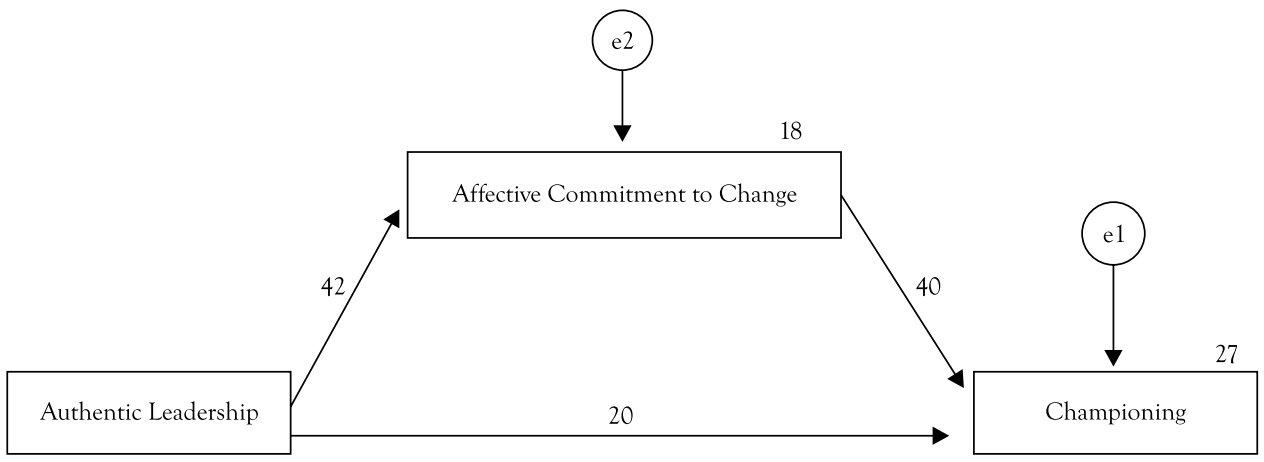

Figure 4: Mediation of ACC

cate that the relationship between authentic leadership and ACC is significant and its regression coefficient is 0.425 . The mediator, ACC is showing positive regression coefficients with championing behaviour (0.400). The p value between ACC and championing is 0.000 . This indicates that both relationships are significant. Therefore, three steps as suggested by Baron and Kenny (1986) are satisfied therefore the study proceeds to identify the mediated effects.

The above table 6 depicts that the standardized regression coefficient of the relationship between authentic leadership and championing before the introduction of mediator is 0.369 and after the introduction it is reduced to 0.199 . The relationship is 
significant. This means that relationship between authentic leadership and championing is partially mediated by ACC. The results therefore provide support for hypothesis 3 that employee affective commitment to change mediates the relationship between authentic leadership and championing behaviour of behavioural support for change.

\section{Discussion}

Hypothesis testing results suggest that authentic leadership is positively related to championing behaviour and the relationship is partially mediated by management support and affective commitment to change. The results of this study are in line with literature as authentic leadership has been found positively contributing to employee behaviours through influencing mechanism of first creating positive beliefs and perceptions (Amunkete \& Rothmann, 2015). These results suggest that authentic leaders by promoting their self as men of integrity can enhance employees' feelings that the change program is viable and supported by principal officers and it will yield benefits to employees (Joo et al., 2013, p. 408; Leroy et al., 2012).

A recent study which analyzed responses from Pakistani public sector employees tested the relationship between commitment to change and behavioural support for change. In their results affective commitment to change was not found positively related to championing behaviour (M. S. Adil, 2016). There was need to retest affective commitment to change with championing behaviour so that relevance of affective commitment to change with Pakistani setting may be verified. In the study of (Herscovitch \& Meyer, 2002) affective commitment to change was found strong predictor of championing behaviour as compared to normative and continuous commitment to change. Results of this study support consensus of literature about the relationship between affective commitment to change and championing behaviour. Moreover, this study further strengthens the claim of Cerne et al. (2013) who found authentic leadership positively related to employee innovation and creativity, employee perception of management support for innovation mediated the relationship. Moreover, this study has answered a call for research by Joo et al. (2013) who suggested to check mediating role of employee perception of being trusted by their leaders (e.g. management support for change; p.406).

\subsection{Significance of Study}

Results of this study are very important as we have provided evidence of model fitness of measurement model through CFA by using three independent samples. We have also provided the evidence of construct validity, convergent validity, reliability, and predictive validity of authentic leadership construct. To the best of our knowledge, this is among the first studies which have provided evidence of validation of authentic 
leadership through providing data from such diverse sources from Pakistani settings. Recent study of A. Adil and Kamal (2016) tested authentic leadership in higher education sector of Punjab and Islamabad and reported positive role of authentic leadership with psychological capital. Our study extends their results by providing across the Pakistan representation of university teachers as well as representative sample of Pakistan Railways and health sector organization sample and reports the validity of ALQ alongwith hypothesis testing.

\subsection{Limitations and Future Recommendations}

Main limitation to this study is the use of cross sectional data. Though timeline of data collection in three samples is different but this study has not reported temporal difference in the data therefore there is need to investigate authentic leadership questionnaire using a longitudinal data. Another limitation may be that this study has used employees' behavioural variables as outcomes of authentic leadership. As authentic leadership is somewhat related with other ethical leadership constructs such as transformational leadership (Banks et al., 2016; Joo \& Nimon, 2014), there is need to root out correlation between authentic leadership and spiritual leadership (Avolio \& Walumbwa, 2014).

Based on the results of this study, which uncover positive relationship of authentic leadership with change related employee attitudes and behaviours, we propose that authentic leadership is highly relevant for Asian countries therefore, scholars should further investigate it to test its importance in prediction of some other important constructs such as change related OCB (J. N. Choi, 2007), cynicism about change (Wanous, Reichers, \& Austin, 2000), and resistance to change (Oreg, 2006). Authentic leadership has also provided important insights regarding employees' psychological processes (e.g. psychological capital; Amunkete \& Rothmann, 2015; Woolley et al., 2010), there is need to investigate the influence authentic leadership may exert on employees' dispositional factors such as dispositional resistance to change (Oreg, 2003).

Although this study has incorporated responses from three different samples from Pakistan, majority of the respondents belonged to public sector organizations and service sector. Therefore, in order to develop more consensus on the validity of ALQ in the Asian context, there is a need to involve more respondents from private sector and manufacturing organizations to know difference among public and private sector employees with regard to concept of authentic leadership. This will help understand employee perception of the authentic leadership in public and private organizations. Moreover, scholars are emphasizing the need for responsible leadership in Asian context, there is need to test whether authentic leadership can correlate positively with Responsible Leadership Scale (Fernando, 2016; Voegtlin, 2011). 


\subsection{Practical Implications}

This study also suggests some practical implications for the organizations, as there is widespread need of ethical and moral leadership (Avolio et al., 2009) the executives need to arrange training programs for middle and senior level managers to develop authentic leadership behaviours in them. As ALQ is globally valid construct (Gardner et al., 2011) and equally valid for Pakistan as per findings of this study, therefore, it may provide valid measurement tool to track the development of authentic leadership behaviours in managers (Walumbwa et al., 2008).

\section{Conclusion}

Aim of this study was to report the reliability and validity of authentic leadership questionnaire. For this, SPSS and AMOS were used to compute Cronbach's alpha, composite reliability, construct validity and structural model. Overall results of this study support the notion that authentic leadership questionnaire may be valid and reliable measure in the organizational change context of developing countries of Asia like Pakistan. Results also suggest that in public sector organizations of Pakistan where corruption and frauds are rampant, leaders' authenticity and integrity is necessary subject of attention. It may provide great source for positive employee behaviours in the organizations which may not only contribute towards organizational effectiveness but for the welfare of society.

\section{References}

Adil, A., \& Kamal, A. (2016). Impact of psychological capital and authentic leadership on work engagement and job related affective well-being. Pakistan Journal of Psychological Research, 31(1), 1-21.

Adil, M. S. (2016). Impact of change readiness on commitment to technological change, focal, and discretionary behaviors. Journal of Organizational Change Management, 29(2), 222-241. doi:10.1108/ jocm-11-2014-0198

Amunkete, S., \& Rothmann, S. (2015). Authentic leadership, psychological capital, job satisfaction and intention to leave in state-owned enterprises. Journal of Psychology in Africa, 25(4), 271-281. doi:10. 1080/14330237.2015.1078082

Andreoli, N., \& Lefkowitz, J. (2009). Individual and organizational antecedents of misconduct in organizations. Journal of Business Ethics, 85(3), 309-332. doi:10.1007/s10551-008-9772-6

Avolio, B. J., \& Gardner, W. L. (2005). Authentic leadership development: Getting to the root of positive forms of leadership. The Leadership Quarterly, 16(3), 315-338. doi:10.1016/j.leaqua.2005.03.001

Avolio, B. J., Gardner, W. L., Walumbwa, F. O., Luthans, F., \& May, D. R. (2004). Unlocking the mask: A look at the process by which authentic leaders impact follower attitudes and behaviors. 
The Leadership Quarterly, 15(6), 801-823.

Avolio, B. J., Griffith, J., Wernsing, T., S. , \& Walumbwa, F., O. (2010). What is authentic leadership development? In N. Garcea, S. Harrington, \& P. A. Linley (Eds.), Oxford Handbook of Positive Psychology and Work (pp. 39-51). New York: NY Oxford University Press.

Avolio, B. J., \& Walumbwa, F. O. (2014). Authentic leadership theory, research and practice: Steps taken and steps that remain. In D. V. Day (Ed.), The Oxford handbook of leadership and organizations (pp. 331-356). New York, NY, US: Oxford University Press.

Avolio, B. J., Walumbwa, F. O., \& Weber, T. J. (2009). Leadership: Current theories, research, and future directions. Annual Review of Psychology, 60(1), 421-449. doi:doi:10.1146/annurev. psych.60.110707.163621

Bagozzi, R. P., Yi, Y., \& Phillips, L. W. (1991). Assessing construct validity in organizational research. Administrative Science Quarterly, 36(3), 421-458. doi:10.2307/2393203

Bakari, H. (2016). How does authentic leadership influence planned organizational change- the role of employees' perceptions (M.Phil thesis), National Defence University, Islamabad, Islamabad. (R-658 HAR)

Bakari, H., Hunjra, A. I., \& Niazi, G. S. K. (2017). How does authentic leadership influence planned organizational change? The role of employees' perceptions: Integration of theory of planned behavior and Lewin's three step model. Journal of Change Management, 17(2), 155-187. doi:10.1080/ 14697017.2017.1299370

Banks, G. C., McCauley, K. D., Gardner, W. L., \& Guler, C. E. (2016). A meta-analytic review of authentic and transformational leadership: A test for redundancy. The Leadership Quarterly, 27(4), 634-652. doi:http://dx.doi.org/10.1016/j.leaqua.2016.02.006

Baron, R. M., \& Kenny, D. A. (1986). The moderator-mediator variable distinction in social psychological research: Conceptual, strategic, and statistical considerations. Journal of personality and social psychology, 51(6), 1173-1182.

Battilana, J., Gilmartin, M., Sengul, M., Pache, A.-C., \& Alexander, J. A. (2010). Leadership competencies for implementing planned organizational change. The Leadership Quarterly, 21(3), 422-438. doi:10.1016/j.leaqua.2010.03.007

Bentler, P. M., \& Bonett, D. G. (1980). Significance tests and goodness of fit in the analysis of covariance structures. Psychological bulletin, 88(3), 588-606. doi:10.1037/0033-2909.88.3.588

Bollen, K. A., \& Stine, R. A. (1992). Bootstrapping goodness-of-fit measures in structural equation models. Sociological Methods $\mathcal{E}$ Research, 21(2), 205-229. doi:10.1177/0049124192021002004

Bouckenooghe, D. (2012). The role of organizational politics, contextual resources, and formal communication on change recipients' commitment to change: A multilevel study. European Journal of Work and Organizational Psychology, 21(4), 575-602. doi:10.1080/1359432x.2011.591573 
Bouckenooghe, D., Schwarz, G. M., \& Minbashian, A. (2015). Herscovitch and Meyer's Three-Component model of commitment to change: Meta-analytic findings. European Journal of Work and Organizational Psychology, 24(4), 578-595. doi:10.1080/1359432X.2014.963059

Burnes, B., \& By, R. T. (2011). Leadership and change: The case for greater ethical clarity. Journal of Business Ethics, 108(2), 239-252. doi:10.1007/s10551-011-1088-2

Carmeli, A., Schaubroeck, J., \& Tishler, A. (2011). How CEO empowering leadership shapes top management team processes: Implications for firm performance. The Leadership Quarterly, 22(2), 399-411. doi:http://dx.doi.org/10.1016/j.leaqua.2011.02.013

Cerne, M., Jaklic, M., \& Skerlavaj, M. (2013). Authentic leadership, creativity, and innovation: A multilevel perspective. Leadership, 9(1), 63-85. doi:10.1177/1742715012455130

Choi, J. N. (2007). Change-oriented organizational citizenship behavior: Effects of work environment characteristics and intervening psychological processes. Journal of Organizational Behavior, 28(4), 467-484. doi: 10.1002/job.433

Choi, M. (2011). Employees' attitudes toward organizational change: A literature review. Human Resource Management, 50(4), 479-500. doi:10.1002/hrm.20434

Cottrill, K., Denise Lopez, P., \& Hoffman, C. C. (2014). How authentic leadership and inclusion benefit organizations. Equality, Diversity and Inclusion: An International Journal, 33(3), 275-292. doi:doi:10.1108/EDI-05-2012-0041

Cronbach, L. J. (1951). Coefficient alpha and the internal structure of tests. psychometrika, 16(3), 297-334.

Cua, K. O., McKone, K. E., \& Schroeder, R. G. (2001). Relationships between implementation of TQM, JIT, and TPM and manufacturing performance. Journal of Operations Management, 19(6), 675-694. doi:http://dx.doi.org/10.1016/S0272-6963(01)00066-3

Darvish, H., \& Rezaei, F. (2011). The impact of authentic leadership on job satisfaction and team commitment. Management $\mathcal{E}$ Marketing, 6(3), 421.

DeVellis, R. F. (1991). Scale Development: Theory and Applications (2nd ed.). Thousand Oaks, CA.: Sage Publications.

Fernando, M. (2016). Responsible leadership in practice Leading Responsibly in the Asian Century (pp. 103-141). Cham: Springer International Publishing.

Fornell, C., \& Larcker, D. F. (1981). Evaluating structural equation models with unobservable variables and measurement error. Journal of Marketing Research, 18(1), 39-50. doi:10.2307/3151312

Fox, J., Gong, T., \& Attoh, P. (2015). The impact of principal as authentic leader on teacher trust in the K 12 educational context. Journal of Leadership Studies, 8(4), 6-18. doi:10.1002/jls.21341

García-Guiu, C., Molero, F., \& Moriano, J. A. (2015). Authentic leadership and its influence on group cohesion and organizational identification: the role of organizational justice as a mediating variable 
/ El liderazgo auténtico y su influencia sobre la cohesión grupal y la identificación organizacional: el papel de la justicia organizacional como variable mediadora. Revista de Psicología Social, 30(1), 60-88. doi:10.1080/02134748.2014.987539

Gardner, W. L., Avolio, B. J., Luthans, F., May, D. R., \& Walumbwa, F. O. (2005). “Can you see the real me?” A self-based model of authentic leader and follower development. The Leadership Quarterly, 16(3), 343-372. doi:10.1016/j.leaqua.2005.03.003

Gardner, W. L., Cogliser, C. C., Davis, K. M., \& Dickens, M. P. (2011). Authentic leadership: A review of the literature and research agenda. The Leadership Quarterly, 22(6), 1120-1145. doi:10.1016/j. leaqua.2011.09.007

Gatling, A., Kang, H. J. A., \& Kim, J. S. (2016). The effects of authentic leadership and organizational commitment on turnover intention. Leadership $\mathcal{E}$ Organization Development Journal, 37(2), 181-199. doi:10.1108/lodj-05-2014-0090

George, B. (2003). Authentic leadership: Rediscovering the secrets to creating lasting value: John Wiley \& Sons.

Giallonardo, L. M., Wong, C. A., \& Iwasiw, C. L. (2010). Authentic leadership of preceptors: Predictor of new graduate nurses' work engagement and job satisfaction. Journal of Nursing Management, 18(8), 993-1003. doi: 10.1111/j.1365-2834.2010.01126.x

Hair, J. F., Black, W. C., Babin, B. J., \& Anderson, R. E. (2010). Multivariate data analysis (7th ed.). New Jerseym NJ: Pearson Prentice Hall.

Harmann, H. H. (1976). Modern factor analysis (3rd ed.). Chicago, IL: University of Chicago Press, Chicago, USA.

Hayes, A. F. (2009). Beyond Baron and Kenny: Statistical mediation analysis in the new millennium. Communication Monographs, 76(4), 408-420. doi:10.1080/03637750903310360

Herscovitch, L., \& Meyer, J. P. (2002). Commitment to organizational change:Eextension of a three-component model. Journal of applied psychology, 87(3), 474. doi:10.1037/0021-9010.87.3.474

Hill, N. S., Seo, M.-G., Kang, J. H., \& Taylor, M. S. (2012). Building employee commitment to change across organizational levels: The influence of hierarchical distance and direct managers' transformational leadership. Organization Science, 23(3), 758-777. doi:10.1287/orsc.1110.0662

Hina Jawaid, K., Berntson, E., Baraldi, S., Näswall, K., \& Sverke, M. (2010). The moderating role of employability on the relationship between job insecurity and commitment to change. Economic and Industrial Democracy, 31(3), 327-344. doi:10.1177/0143831x09351214

Holt, D. T., Armenakis, A. A., Feild, H. S., \& Harris, S. G. (2007). Readiness for organizational change: The systematic development of a scale. The Journal of applied behavioral science, 43(2), 232-255. doi: $10.1177 / 0021886306295295$

Hsiung, H.-H. (2012). Authentic leadership and employee voice behavior: A multi-level psychological 
process. Journal of Business Ethics, 107(3), 349-361. doi:10.1007/s10551-011-1043-2

Hu, L. t., \& Bentler, P. M. (1999). Cutoff criteria for fit indexes in covariance structure analysis: Conventional criteria versus new alternatives. Structural Equation Modeling: A Multidisciplinary Journal, 6(1), 1-55.

Ilies, R., Morgeson, F. P., \& Nahrgang, J. D. (2005). Authentic leadership and eudaemonic well-being: Understanding leader-follower outcomes. The Leadership Quarterly, 16(3), 373-394. doi:http:// dx.doi.org/10.1016/j.leaqua.2005.03.002

Jacques, P. H., Garger, J., Lee, K., \& Ko, J.-Y. (2015). Authentic leadership on the frontline and its effects on Korean restaurant employees. Journal of Foodservice Business Research, 18(4), 389-403. doi:10.10 80/15378020.2015.1068674

Joo, B.-K., McLean, G. N., \& Yang, B. (2013). Creativity and human resource development: An integrative literature review and a conceptual framework for future research. Human Resource Development Review, 12(4), 390-421. doi:10.1177/1534484313481462

Joo, B.-K., \& Nimon, K. (2014). Two of a kind? A canonical correlational study of transformational leadership and authentic leadership. European Journal of Training and Development, 38(6), 570-587. doi:10.1108/EJTD-12-2013-0129

Kernis, M. H. (2003). Toward a conceptualization of optimal self-esteem. Psychological Inquiry, 14(1), 1-26. doi:10.1207/S15327965PLI1401_01

Kiersch, C. E., \& Byrne, Z. S. (2015). Is being authentic being fair? Multilevel examination of authentic leadership, justice, and employee outcomes. Journal of Leadership $\mathcal{E}$ Organizational Studies, 22(3), 292-303. doi: $10.1177 / 1548051815570035$

Kiratli, N., Rozemeijer, F., Hilken, T., de Ruyter, K., \& de Jong, A. (2016). Climate setting in sourcing teams: Developing a measurement scale for team creativity climate. Journal of Purchasing and Supply Management, 22(3), 196-204. doi:10.1016/j.pursup.2016.04.006

Lagan, T. E. (2007). Examining authentic leadership: Development of a four-dimensional scale and identification of a nomological network. (PhD Dissertations), State University of New York at Albany, Ann Arbor. Retrieved from http://search.proquest.com/docview/304742700 (3270277)

Laschinger, H. K. S., Cummings, G., Leiter, M., Wong, C. A., MacPhee, M., Ritchie, J., . . Read, E. (2016). Starting Out: A time-lagged study of new graduate nurses' transition to practice. International Journal of Nursing Studies, 57, 82-95. doi:10.1016/j.ijnurstu.2016.01.005

Laschinger, H. K. S., \& Fida, R. (2014). A time-lagged analysis of the effect of authentic leadership on workplace bullying, burnout, and occupational turnover intentions. European Journal of Work and Organizational Psychology, 23(5), 739-753. doi:10.1080/1359432X.2013.804646

Leroy, H., Anseel, F., Gardner, W. L., \& Sels, L. (2015). Authentic leadership, authentic followership, basic need satisfaction, and work role performance: A cross-level study. Journal of Management, 41(6), 
1677-1697. doi: $10.1177 / 0149206312457822$

Leroy, H., Palanski, M. E., \& Simons, T. (2012). Authentic leadership and behavioral integrity as drivers of follower commitment and performance. Journal of Business Ethics, 107(3), 255-264. doi:10.1007/ s10551-011-1036-1

Lines, B. C., Sullivan, K. T., \& Wiezel, A. (2016). Support for organizational change: Change-readiness outcomes among AEC project teams. Journal of Construction Engineering and Management, 142(2), 04015062. doi:10.1061/(asce)co.1943-7862.0001043

Luthans, F., \& Avolio, B. J. (2003). Authentic leadership development. San Francisco: Berrett-Koehler Publishers.

May, D. R., Chan, A. Y., Hodges, T. D., \& Avolio, B. J. (2003). Developing the moral component of authentic leadership. Organizational Dynamics, 32(3), 247-260.

Müceldili, B., Turan, H., \& Erdil, O. (2013). The influence of authentic leadership on creativity and innovativeness. Procedia - Social and Behavioral Sciences, 99, 673-681. doi:http://dx.doi.org/10.1016/j. sbspro.2013.10.538

Neider, L. L., \& Schriesheim, C. A. (2011). The Authentic Leadership Inventory (ALI): Development and empirical tests. The Leadership Quarterly, 22(6), 1146-1164. doi:http://dx.doi.org/10.1016/j. leaqua.2011.09.008

Nelson, K., Boudrias, J.S., Brunet, L., Morin, D., De Civita, M., Savoie, A., \& Alderson, M. (2014). Authentic leadership and psychological well-being at work of nurses: The mediating role of work climate at the individual level of analysis. Burnout Research, 1(2), 90-101. doi:10.1016/j.burn.2014.08.001

Onorato, M., \& Zhu, J. (2015). The relationship between authentic leadership and employee job satisfaction: A cross-industry-sector empirical study. International Leadership Journal, 7(2).

Oreg, S. (2003). Resistance to change: Developing an individual differences measure. Journal of applied psychology, 88(4), 680-693. doi:10.1037/0021-9010.88.4.680

Oreg, S. (2006). Personality, context, and resistance to organizational change. European Journal of Work and Organizational Psychology, 15(1), 73-101. doi:10.1080/13594320500451247

Pakistan-Railways. (2015). Year Book 2014-2015. Retrieved from http://www.railways.gov.pk/

Penger, S., \& Černe, M. (2014). Authentic leadership, employees' job satisfaction, and work engagement: A hierarchical linear modelling approach. Economic Research-Ekonomska Istraživanja, 27(1), 508-526. doi:10.1080/1331677X.2014.974340

Peus, C., Wesche, J. S., Streicher, B., Braun, S., \& Frey, D. (2012). Authentic leadership: An empirical test of its antecedents, consequences, and mediating mechanisms. Journal of Business Ethics, 107(3), 331-348. doi:10.1007/s10551-011-1042-3

Preacher, K. J., \& Hayes, A. F. (2004). SPSS and SAS procedures for estimating indirect effects in simple 
mediation models. Behavior Research Methods, Instruments, $\mathcal{E}$ Computers, 36(4), 717-731. doi:10.3758/ bf03206553

Read, E. A., \& Laschinger, H. K. S. (2015). The influence of authentic leadership and empowerment on nurses' relational social capital, mental health and job satisfaction over the first year of practice. Journal of Advanced Nursing, 71(7), 1611-1623. doi:10.1111/jan.12625

Regan, S., Laschinger, H. K., \& Wong, C. A. (2016). The influence of empowerment, authentic leadership, and professional practice environments on nurses' perceived interprofessional collaboration. J Nurs Manag, 24(1), E54-61. doi:10.1111/jonm.12288

Rego, P., Lopes, M. P., \& Nascimento, J. L. (2016). Authentic leadership and organizational commitment: The mediating role of positive psychological capital. Journal of Industrial Engineering and Management, 9(1), 129.

Roof, R. (2014). Authentic leadership questionnaire (ALQ) psychometrics. Asian Journal of Business Ethics, 3(1), 57-64.

Santhidran, S., Chandran, V. G. R., \& Borromeo, J. (2013). Enabling organizational change - leadership, commitment to change and the mediating role of change readiness. Journal of Business Economics and Management, 14(2), 348-363. doi:10.3846/16111699.2011.642083

Shapira-Lishchinsky, O., \& Tsemach, S. (2014). Psychological empowerment as a mediator between teachers' perceptions of authentic leadership and their withdrawal and citizenship behaviors. Educational Administration Quarterly, 50(4), 675-712. doi:10.1177/0013161x13513898

Sobel, M. E. (1982). Asymptotic confidence intervals for indirect effects in structural equation models. Sociological methodology, 13, 290-312.

Steenkamp, J.-B. E. M., \& Baumgartner, H. (2000). On the use of structural equation models for marketing modeling. International Journal of Research in Marketing, 17(2-3), 195-202. doi:http://dx.doi. org/10.1016/S0167-8116(00)00016-1

Treviño, L. K., Nieuwenboer, N. A. d., \& Kish-Gephart, J. J. (2014). (Un)Ethical Behavior in Organizations. Annual Review of Psychology, 65(1), 635-660. doi:10.1146/annurev-psych-113011-143745

van der Voet, J. (2015). Change Leadership and Public Sector Organizational Change: Examining the Interactions of Transformational Leadership Style and Red Tape. The American Review of Public Administration, 46(6), 660-682. doi:10.1177/0275074015574769

Voegtlin, C. (2011). Development of a scale measuring discursive responsible leadership. Journal of Business Ethics, 98(1), 57-73. doi:10.1007/s10551-011-1020-9

Walumbwa, F. O., Avolio, B. J., Gardner, W. L., Wernsing, T. S., \& Peterson, S. J. (2008). Authentic leadership: Development and validation of a theory-based measure. Journal of Management, 34(1), 89-126. doi:10.1177/0149206307308913 
Wanous, J. P., Reichers, A. E., \& Austin, J. T. (2000). Cynicism about organizational change: Measurement, antecedents, and correlates. Group E Organization Management, 25(2), 132-153. doi: $10.1177 / 1059601100252003$

Warszewska-Makuch, M., Bedyńska, S., \& Żołnierczyk-Zreda, D. (2015). Authentic leadership, social support and their role in workplace bullying and its mental health consequences. International Journal of Occupational Safety and Ergonomics, 21(2), 128-140. doi:10.1080/10803548.2015.1028230

Williams, E. A., Pillai, R., Deptula, B., \& Lowe, K. B. (2012). The effects of crisis, cynicism about change, and value congruence on perceptions of authentic leadership and attributed charisma in the 2008 presidential election. The Leadership Quarterly, 23(3), 324-341. doi:10.1016/j.leaqua.2011.07.003

Wong, C. A., \& Laschinger, H. K. S. (2013). Authentic leadership, performance, and job satisfaction: The mediating role of empowerment. Journal of Advanced Nursing, 69(4), 947-959. doi:10.1111/j.13652648.2012.06089.x

Wong, C. A., Spence Laschinger, H. K., \& Cummings, G. G. (2010). Authentic leadership and nurses' voice behaviour and perceptions of care quality. Journal of Nursing Management, 18(8), 889-900. doi:10.1111/j.1365-2834.2010.01113.x

Woolley, L., Caza, A., \& Levy, L. (2010). Authentic leadership and follower development: Psychological capital, positive work climate, and gender. Journal of Leadership $\mathcal{E}$ Organizational Studies, 18(4), 438448. doi:10.1177/1548051810382013

Yoon, D., Jang, J., \& Lee, J. (2016). Environmental management strategy and organizational citizenship behaviors in the hotel industry: The mediating role of organizational trust and commitment. International Journal of Contemporary Hospitality Management, 28(8), 1577-1597. doi:doi:10.1108/ IJCHM-10-2014-0498

Zubair, A., \& Kamal, A. (2015). Authentic leadership and creativity: Mediating role of work-related flow and psychological capital. Journal of Behavioural Sciences, 25(1), 150. 
